\title{
Antibiotic with Essential Metals Complexation and Interaction, An in Vitro Study by Spectrophotometric Method
}

\author{
Jinnat Begam Tumpa and Md Shahidul Islam* \\ Department of Pharmacy, University of science and Technology Chittagong (USTC), Bangladesh
}

*Corresponding author: Md Shahidul Islam, Department of Pharmacy, University of Science \& Technology Chittagong (USTC), Bangladesh.

To Cite This Article: Md Shahidul Islam. Antibiotic with Essential Metals Complexation and Interaction, An in Vitro Study by Spectrophotometric Method. Am J Biomed Sci \& Res. 2019 - 3(1). AJBSR.MS.ID.000640. DOI: 10.34297/AJBSR.2019.03.000640

Received: May 05, 2019 | Published: May 24, 2019

\begin{abstract}
The present research work describes of interaction and complexation studies of Amoxicillin with essential metal \& antacid and also investigation of antimicrobial activity of Amoxicillin. Amoxicillin included the third generation drug of penicillin. In vitro analysis, Amoxicillin must be interacted with metal like $\mathrm{Mg}^{2+}$ and $\mathrm{Mn}^{2+}$. At pH 7.4, this study was performed in different ratios of Amoxicillin with metal and antacid both at room temperature 250 0C. by this study, it is investigated that drug Amoxicillin is complexed with metal as well as antacid which is confirmed by job's plot. This experiment was carried out by using ultra violet spectrophotometer. The microbial sensitivity test is important to know whether there is any change in the effectivity of Amoxicillin after the interaction with metals. There was a remarkable change in the effectivity of Amoxicillin and its complexes. This research work confirms that there was interaction between Amoxicillin with Metals like $\mathrm{Mg}^{2+}$ and $\mathrm{Mn}^{2+}$ which was confirmed by Job's plot method by spectrophotometric assay.
\end{abstract}

Keywords: Amoxicillin; Complexation; Interaction; Job’s plot

\section{Introduction}

A drug interaction is said to occur when the effects of one drug are changed by the presence of another drug, herbal medicine, food, drink or by some environmental chemical agent. These unwanted and unsought-for interactions are adverse and undesirable but there are other interactions that can be beneficial and valuable, such as the deliberate co-prescription of antihypertensive drugs and diuretics in order to achieve antihypertensive effects possibly not obtainable with either drug alone. The mechanisms of both types of interaction, whether adverse or beneficial, are often very similar [1]. There are different types of drug interactions: Drug-drug interact ions, Drug-herbal interact ions, Food-drug interact ions etc [2]. Drug interactions are complex and chiefly unpredictable. A known interaction may not occur in every individual. This can be explained because there are several factors that effects the likelihood that a known interaction will occur [3]. Zinc is an important co-factor for several enzymatic reactions in the human body, vitamin B12 has cobalt atom and its core, and hemoglobin contains iron. Like $\mathrm{Cu}$, $\mathrm{Mn}, \mathrm{Se}, \mathrm{Cr}$, Mo are all trace elements, which are important in the human diet. Another subset of metals include those used in thera peutically in medicine, Al, bi, Au, Ga, Li and Ag are all part of medical armamentarium [4].
Humans need a certain amount of certain metals to function normally. Most metals are used as cofactors or prosthetics in enzymes, catalyzing specific reactions and serving essential roles. Anemia symptoms are caused by lack of a certain essential metal. Anemia can be associated with malnourishment or faulty metabolic processes, usually caused by a genetic defect [5]. The metal complexes can be utilized for the transport of selected organic chemotherapeutic drugs to target organs, or for the de-corporation of those toxic organic compounds which are able, before or after metabolic activation of reacting with metals or 1:1 complex [6]. It is emphasized that degree to which metal ions interact in vivo should employ the conditional constants which take into account competition from other ions specially $\mathrm{Ca}^{2+}, \mathrm{H}^{+}$and $\mathrm{OH}^{-}$[7]. The genotoxic consequences of the virus chemical factors involved in chelation, along with examples; kinetics, stabilization or oxidation state, lipophilicity, the mixed ligand formation, are discussed [8]. Amoxicillin is a semi-synthetic, moderate spectrum of penicillin group of antibiotics. Amoxicillin is an antibiotic that is used for the treatment of a variety of bacterial infections, skin and urinary tract infections, pneumonia, and strep throat. It binds to one of the penicillin binding proteins which inhibits the final transpeptidation step of the 
peptidoglycan synthesis in the bacterial cell wall, thus inhibiting biosynthesis and arresting cell wall assembly resulting in bacterial cell death [9]. Amoxicillin is a broad-spectrum antibiotic and is commonly used to treat bacterial infections of the ear, urinary tract, and upper respiratory tract [10].

\section{Materials and Methods}

In this study, all the chemical substances, reagents used here were pure and were kept under sorted under suitable conditions [11].

\section{Preparation of stock solution [12]}

In this study, $250 \mathrm{ml}$ of $1 \times 10^{-2}$ stock solution of Amoxicillin was measured by 0.16902 gm of Amoxicillin in $250 \mathrm{ml}$ of demineralized water in a $250 \mathrm{ml}$ volumetric flask. This solution was further diluted to expected concentration by using buffer solution.

\section{Preparation of metal solution [12]}

In this study, $0.1 \mathrm{M}$ metal solution, Magnesium sulphate hepata hydrate, $\mathrm{MgSO}_{4} .7 \mathrm{H}_{2} \mathrm{O}(0.24648 \mathrm{gm})$ was measured perfectly as well as the last solutions were $0.01 \mathrm{M}$ concentration.

\section{Preparation of buffer solution [12]}

In this study, for the preparation of buffer solution, firstly 8.06 gm of $\mathrm{Na}_{2} \mathrm{HPO}_{4}$ was mixed in demineralized water with $1.05 \mathrm{gm}$ of $\mathrm{NaH} 2 \mathrm{PO} 4$ and then pH 7.4 was confirmed.

\section{Preparation of standard curve of Amoxicillin [13]}

In this study, Amoxicillin stock solution at $\mathrm{pH} 7.4$ and concentration $1 \times 10^{-5} \mathrm{M}$ was mixed in different concentrations like: $9 \times 10^{-5} \mathrm{M}$, $8 \times 10^{-5} \mathrm{M}, 7 \times 10-5 \mathrm{M}, 6 \times 10^{-5} \mathrm{M}, 5 \times 10^{-5} \mathrm{M}, 4 \times 10^{-5} \mathrm{M}, 3 \times 10^{-5} \mathrm{M}, 2 \times 10^{-5} \mathrm{M}$, $1 \times 10^{-5} \mathrm{M}$. The absorbance volume of the solutions was determined at $256 \mathrm{~nm}$ by UV spectrometer.

\begin{tabular}{|c|c|c|}
\hline \multicolumn{3}{|c|}{ Table 1: List of chemicals and reagents. } \\
\hline Sl. No. & Name & Source \\
\hline 1 & Amoxicillin & $\begin{array}{c}\text { Gift samples from alvion } \\
\text { laboratories ltd }\end{array}$ \\
\hline 2 & Magnesium sulfate & Merck ltd, Mumbai, India \\
\hline 3 & Manganese sulfate & Merck ltd, Mumbai, India \\
\hline 4 & Sodium di-hydrogen phosphate & $\begin{array}{r}\text { USTC, Foys lake, Chittagong, } \\
\text { dept of pharmacy }\end{array}$ \\
\hline 5 & Disodium hydrogen phosphate & $\begin{array}{r}\text { USTC, Foys lake, Chittagong, } \\
\text { dept of pharmacy }\end{array}$ \\
\hline
\end{tabular}

\begin{tabular}{|c|c|c|}
\hline \multicolumn{3}{|c|}{ Table 2: List of instruments and equipment. } \\
\hline Name & Model & source \\
\hline PH Meter & PH-211 & Hanna,Romania \\
\hline UV spectrophotometer & T80 & $\begin{array}{c}\text { PG instrument ltd, } \\
\text { England }\end{array}$ \\
\hline Electronic balance & AL-204 & $\begin{array}{c}\text { Mettler toleddo, Swit- } \\
\text { zerland }\end{array}$ \\
\hline Micropipette & & $\begin{array}{c}\text { Fischer scientific, Ger- } \\
\text { many }\end{array}$ \\
\hline
\end{tabular}

All the equipment and instruments used throughout the study are given in the following table along with their source. From the above Table we can observe that the absorbance of amoxicillin increases with increasing concentration according to Beer Lambert's law. From the above Table we can observe that the absorbance of amoxicillin varies at different wavelength (Tables 1-4).

\begin{tabular}{|c|c|}
\hline Table 3: Standards curve of Amoxicillin. \\
\hline Mx10-5 & Absorbance \\
\hline 1 & 0.051 \\
\hline 2 & 0.068 \\
\hline 3 & 0.102 \\
\hline 4 & 0.118 \\
\hline 5 & 0.135 \\
\hline 6 & 0.184 \\
\hline 7 & 0.202 \\
\hline 8 & 0.237 \\
\hline 9 & 0.272 \\
\hline
\end{tabular}

Table 4: Absorbance of Amoxicillin at different wavelength.

\begin{tabular}{|c|c|}
\hline Wavelength & Absorbance \\
\hline 200 & 1.5 \\
\hline 210 & 0.87 \\
\hline 220 & 0.65 \\
\hline 230 & 0.25 \\
\hline 240 & 0.62 \\
\hline 250 & 0.79 \\
\hline 260 & 0.93 \\
\hline 270 & 0.65 \\
\hline 280 & 0.53 \\
\hline 290 & 0.007 \\
\hline
\end{tabular}

\section{Results and Discussion}

\begin{tabular}{|c|c|c|}
\hline Wavelength/nm & $\begin{array}{l}\text { Absorbance of amox- } \\
\text { icillin }\end{array}$ & $\begin{array}{l}\text { Absorbance of amoxi- } \\
\text { cillin }+\mathrm{MgSO}_{4} \cdot 7 \mathrm{H}_{2} \mathrm{O}\end{array}$ \\
\hline 200 & 1.5 & 1.3 \\
\hline 210 & 0.87 & 0.95 \\
\hline 220 & 0.65 & 0.91 \\
\hline 230 & 0.25 & 0.87 \\
\hline 240 & 0.62 & 0.62 \\
\hline 250 & 0.79 & 0.53 \\
\hline 260 & 0.93 & 0.49 \\
\hline 270 & 0.65 & 0.37 \\
\hline 280 & 0.53 & 0.031 \\
\hline 290 & 0.007 & 0.007 \\
\hline
\end{tabular}

From the above Table we can observe that the absorbance of amoxicillin is different when it interacts with $\mathrm{MgSO}_{4} \cdot 7 \mathrm{H}_{2} \mathrm{O}$. From the above Table we can observe that the absorbance of amoxicillin is different when it interacts with $\mathrm{MnSO}_{4} \cdot \mathrm{H}_{2} \mathrm{O}$. This table shows that absorbance of amoxicillin is quite different from absorbance of amoxicillin and metal complexes (Table 5). The intensity of the peak of amoxicillin changes remarkably i.e. absorption character- 
istics are altered due to interaction, but the position of the compound does not shift. Interaction between drug and metal may lead to form complexes which have different light absorption capacity and spectrum pattern is altered.

\section{Effect of metals on Amoxicillin by Job's method of con-} tinuous variation

The molar ratios of the complexes of amoxicillin with metal salts were estimated by job's method of continuous variation. The observed absorbance values were measured in $\mathrm{pH} 7.4$ at various concentration $\left(1 \times 10^{-5}\right.$ to $\left.9 \times 10^{-5} \mathrm{M}\right)$ of amoxicillin and metal salts at $2310 \mathrm{~nm}$. The Job's plots at $\mathrm{pH} 7.4$ were obtained by plotting absorbance difference against the mole fraction of the drug (amoxicillin) which are presented in the following table. From the above table we can observe that amoxicillin forms strong 1:1 complex with magnesium Sulfate hepta hydrate which is indicated as ' $\wedge$ ' shaped curve. From the above table we can observe that amoxicillin forms strong 1:1 complex with manganese Sulfate mono hydrate which is indicated as '^' shaped curve (Table 6).

\begin{tabular}{|c|c|c|}
\hline Table 6: Spectral analysis of Amoxicillin with $\mathrm{MnSO}_{2} \cdot \mathrm{H}_{2} \mathrm{O}$. & Absorbance of amoxicillin $+\mathbf{M n S O}_{\mathbf{4}} \cdot \mathbf{\mathbf { H } _ { \mathbf { 2 } } \mathbf { O }}$ \\
\hline Wavelength/nm & Absorbance of amoxicillin & 0.88 \\
\hline 200 & 1.5 & 0.84 \\
\hline 210 & 0.87 & 0.63 \\
\hline 220 & 0.65 & 0.52 \\
\hline 230 & 0.25 & 0.77 \\
\hline 240 & 0.62 & 0.62 \\
\hline 250 & 0.79 & 0.32 \\
\hline 260 & 0.93 & 0.19 \\
\hline 270 & 0.65 & 0.045 \\
\hline 280 & 0.53 & 0.013 \\
\hline 290 & 0.007 & \\
\hline
\end{tabular}

\section{Combined absorbance of drug with different metal}

\begin{tabular}{|c|c|c|c|c|c|}
\hline \multicolumn{6}{|c|}{ Table 7: Values of job plot of amoxicillin and $\mathrm{MnSO}_{4} .7 \mathrm{H}_{2} \mathrm{O}$. } \\
\hline $\begin{array}{c}\text { Concentration of } \\
\text { amoxicillin } \mathrm{M} \times 10^{-5}\end{array}$ & $\begin{array}{c}\text { Absorbance of amox- } \\
\text { icillin A }\end{array}$ & $\begin{array}{l}\text { Concentration of Mg- } \\
\mathrm{SO}_{4} \cdot 7 \mathrm{H}_{2} \mathrm{O} \mathrm{M} \times 10^{-5}\end{array}$ & $\begin{array}{c}\text { Absorbance of Mg- } \\
\mathrm{SO}_{4} \cdot 7 \mathrm{H}_{2} \mathrm{O} \mathrm{B}\end{array}$ & $\begin{array}{c}\text { Absorbance of mix- } \\
\text { ture C }\end{array}$ & $\begin{array}{c}\text { Absorbance differ- } \\
\text { ence }\end{array}$ \\
\hline \multicolumn{6}{|l|}{$D=(A+B)-C$} \\
\hline 1 & 0.051 & 9 & 0.069 & 0.043 & 0.077 \\
\hline 2 & 0.068 & 8 & 0.072 & 0.048 & 0.092 \\
\hline 3 & 0.102 & 7 & 0.078 & 0.056 & 0.124 \\
\hline 4 & 0.118 & 6 & 0.084 & 0.061 & 0.141 \\
\hline 5 & 0.135 & 5 & 0.134 & 0.067 & 0.202 \\
\hline 6 & 0.184 & 4 & 0.110 & 0.060 & 0.234 \\
\hline 7 & 0.202 & 3 & 0.101 & 0.125 & 0.178 \\
\hline 8 & 0.237 & 2 & 0.056 & 0.156 & 0.137 \\
\hline 9 & 0.272 & 1 & 0.012 & 0.187 & 0.097 \\
\hline
\end{tabular}

Table 8: Values of job plot of amoxicillin and $\mathrm{MnSO}_{2} \cdot \mathrm{H}_{2} \mathrm{O}$.

\begin{tabular}{|c|c|c|c|c|c|}
\hline $\begin{array}{c}\text { Concetration of } \\
\text { amoxicillin } M \times 10^{-5}\end{array}$ & $\begin{array}{c}\text { Absorbance of amox- } \\
\text { icillin A }\end{array}$ & $\begin{array}{c}\text { Concentration of } \\
\mathrm{MnSO}_{4} \cdot \mathrm{H}_{2} \mathrm{O} \mathrm{M} \times 10^{-5}\end{array}$ & $\begin{array}{l}\text { Absorbance of } \\
\mathrm{MnSO}_{4} \cdot \mathrm{H}_{2} \mathrm{O} \mathrm{B}\end{array}$ & $\begin{array}{c}\text { Absorbance of mix- } \\
\text { ture C }\end{array}$ & $\begin{array}{c}\text { Absorbance differ- } \\
\text { ence } D=(A+B)-C\end{array}$ \\
\hline 1 & 0.051 & 9 & 0.205 & 0.078 & 0.178 \\
\hline 2 & 0.068 & 8 & 0.195 & 0.072 & 0.191 \\
\hline 3 & 0.102 & 7 & 0.186 & 0.082 & 0.212 \\
\hline 4 & 0.118 & 6 & 0.182 & 0.055 & 0.245 \\
\hline 5 & 0.135 & 5 & 0.176 & 0.017 & 0.294 \\
\hline 6 & 0.184 & 4 & 0.112 & 0.039 & 0.257 \\
\hline 7 & 0.202 & 3 & 0.097 & 0.071 & 0.228 \\
\hline 8 & 0.237 & 2 & 0.052 & 0.096 & 0.193 \\
\hline 9 & 0.272 & 1 & 0.019 & 0.128 & 0.163 \\
\hline
\end{tabular}


The above table shows that the absorbance of amoxicillin differs from the absorbance of amoxicillin $+\mathrm{MgSO}_{4} \cdot 7 \mathrm{H}_{2} \mathrm{O}$ and amoxi- cillin $+\mathrm{MnSO}_{4} \cdot \mathrm{H}_{2} \mathrm{O}$ due to interaction and complexation with antibiotic and metals (Tables 7-9).

Table 9: Combined absorbance of drug with different metal.

\begin{tabular}{|c|c|c|}
\hline Amoxicillin & Amoxicillin+MgSO ${ }_{4} \cdot 7 \mathrm{H}_{2} \mathrm{O}$ & \multicolumn{2}{|c|}{ Amoxicillin+MnSO $\mathrm{M}_{4} \cdot \mathrm{H}_{2} \mathrm{O}$} \\
\hline 0.051 & 0.043 & 0.078 \\
\hline 0.068 & 0.048 & 0.07 \\
\hline 0.102 & 0.056 & 0.08 \\
\hline 0.118 & 0.061 & 0.055 \\
\hline 0.135 & 0.067 & 0.039 \\
\hline 0.184 & 0.06 & 0.071 \\
\hline 0.202 & 0.125 & 0.096 \\
\hline 0.237 & 0.156 & 0.128 \\
\hline 0.272 & 0.187 & 0.2 \\
\hline
\end{tabular}

\section{Conclusion}

In the present work, the interaction of an important antimicrobial drug, amoxicillin $+\mathrm{MgSO}_{4} \cdot 7 \mathrm{H}_{2} \mathrm{O}$ and amoxicillin $+\mathrm{MnSO}_{4}$. $\mathrm{H}_{2} \mathrm{O}$ at 7.4 by a variety of physical method like inspection of spectral behavior, Job's method of continuous variation. From spectral study, it has been seen that Amoxicillin gives a sharp peak at 256 $\mathrm{nm}$. When $\mathrm{MgSO}_{4} \cdot 7 \mathrm{H}_{2} \mathrm{O}$ and $\mathrm{MnSO}_{4} \cdot \mathrm{H}_{2} \mathrm{O}$ salt mixed with Amoxicillin at $1: 1$ ratio, the intensity of the peak changes remarkably specifically absorbance decreases. That's why absorption characteristics are altered due to interaction but the position of the compound does not shift. The Job's plot has given the molar ratio of complexes of amoxicillin $+\mathrm{MgSO}_{4} \cdot 7 \mathrm{H}_{2} \mathrm{O}$ and amoxicillin $+\mathrm{MnSO}_{4} \cdot \mathrm{H}_{2} \mathrm{O}$. At $\mathrm{pH} 7.4$ Amoxicillin forms strong 1:1 complexes with metals $\mathrm{MgSO}_{4} \cdot 7 \mathrm{H}_{2} \mathrm{O}$ and $\mathrm{MnSO}_{4} \cdot \mathrm{H}_{2} \mathrm{O}$ indicated as ' $\wedge$ ' shaped curves. These curves may indicate strong kinetics of complexation between amoxicillin with $\mathrm{MgSO}_{4} \cdot 7 \mathrm{H}_{2} \mathrm{O}$ and amoxicillin with $\mathrm{MnSO}_{4} \cdot \mathrm{H}_{2} \mathrm{O}$. When drug individually act with metals $\mathrm{MgSO}_{4} \cdot 7 \mathrm{H}_{2} \mathrm{O}$ and $\mathrm{MnSO}_{4} \cdot \mathrm{H}_{2} \mathrm{O}$ curve of their absorbance are verify. By this research work, it helps in the study of selection the best dosage form for better treatment. And definitely very important in adjusting the effective dose and dose ranges.

\section{References}

1. Karen Baxter (2008) Stockley's Drug Interactions. $8^{\text {th }}$ edn, Stockley's drug interactions 2008 pocket companion. Can Fam Physician 54(7): 1025 .

2. Shargel L (2010) Comprehensive pharmacy review. Lippincott Williams \& Wilkins, USA.

3. Herfindal ET, Hirschman JL (1979) Clinical pharmacy and therapeutics. Williams \& Wilkins, USA.

4. Zhang L, Reynolds KS, Zhao P, Huang SM (2010) Drug interactions evaluation: an integrated part of risk assessment of therapeutics. Toxicol Appl Pharmacol 243(2): 134-45.
5. Butt EM, Nusbaum RE, Gilmoult TC, Didio SL (1956) Trace metal patterns in disease states: I. Hemochromatosis and refractory anemia. Am J Clin Pathol 26(3): 225-242.

6. Martell AE, Smith RM (1974) Critical stability constants. New York, USA.

7. Davis JA, Leckie JO (1978) Surface ionization and complexation at the oxide/water interface II. Surface properties of amorphous iron oxyhydroxide and adsorption of metal ions. Journal of Colloid and Interface Science 67(1): 90-107.

8. Okamoto OK, Pinto E, Latorre LR, Bechara EJ, Colepicolo P, et al. (2001) Antioxidant modulation in response to metal-induced oxidative stress in algal chloroplasts. Archives of Environmental Contamination and Toxicology 40(1): 18-24.

9. Tsuji, A, Terasaki T, Tamai I, Hirooka H (1987) H+ gradient-dependent and carrier-mediated transport of cefixime, a new cephalosporin antibiotic, across brush-border membrane vesicles from rat small intestine. Journal of Pharmacology and Experimental Therapeutics 241(2): 594-601.

10. Furman WL, Crews KR, Billups C, Wu J, Gajjar AJ, et al. (2006) Cefixime allows greater dose escalation of oral irinotecan: a phase I study in pediatric patients. J Clin Oncol 24(4): 563-570.

11. Frankenberger W, Dick WA (1983) Relationships between enzyme activities and microbial growth and activity indices in soil. Soil Science Society of America Journal 47(5): 945-951.

12. Md. Shahidul Islam, Sabekun Binte Monsur (2018) "An Interaction Study of Metal Ions Complexation with Cephradine on Its Antibacterial Activity." International Research Journal of Pharmacy and Medical Sciences (IRJPMS) 1(4): 17-20.

13. MD. Shahidul Islam and Nobina Akter, "In-Vitro interaction of cefpodoximeproxetil with different essential metal, antacids and investigation of antimicrobial activity." International Research Journal of Pharmacy and Medical Sciences (IRJPMS) 2(1): 70-73. 